\title{
Clonal structure of Shiga toxin (Stx)-producing and $\beta$-D-glucuronidase-positive Escherichia coli 0157:H7 strains isolated from outbreaks and sporadic cases in Hokkaido, Japan
}

\author{
HIDEKI NAGANO, TOYO OKUI, OSAMU FUJIWARA, YASUHIRO UCHIYAMA, NAOTO TAMATE, \\ HIROYUKI KUMADA, YO MORIMOTO and SHOKI YANO
}

Hokkaido Institute of Public Health, North-19, West-12, Kita-ku, Sapporo 060-0819, Japan

\begin{abstract}
A total of 22 clonal phenotypic variants of Shiga toxin (Stx)-producing Escherichia coli (STEC) 0157:H7 was isolated from six different locations in Hokkaido, Japan. These isolates were negative for sorbitol fermentation but positive for $\beta$-D-glucuronidase $\left(G^{+}\right)$. They carried eaeA, EHEC-hlyA, pas and etpD genes like typical E. coli O157:H7 and, in addition, stx 1 and stx 2 genes. However, they were shown to lack katP and espP genes that are present in typical STEC 0157:H7. All these atypical GUD ${ }^{+}$ STEC 0157:H7 isolates had very similar antimicrobial susceptibilities. Pulsed-field gel electrophoresis analysis with $\mathrm{XbaI}, S$ fiI, SwaI, SpeI and NotI indicated that they were identical or closely related to one another. From their phenotypic and genotypic features, these GUD ${ }^{+}$STEC O157:H7 isolates may represent a distinct clone among STEC 0157.
\end{abstract}

\section{Introduction}

Shiga toxin (Stx)-producing Escherichia coli (STEC) or enterohaemorrhagic E. coli (EHEC) O157:H7 is now recognised as a serious food-borne pathogen, causing severe bloody diarrhoea with abdominal cramps and, occasionally, haemolytic-uraemic syndrome (HUS) [1]. STEC has an ability to produce one or more Stxs (Stx1, Stx2, or variants) responsible for serious illness in man $[2,3]$. It is thought that HUS results from the systemic action of Stx on vascular endothelial cells [4] but other factors which have an influence on the virulence of toxigenic E. coli $\mathrm{O} 157$ also seem to be required. The locus of enterocyte effacement (LEE) in this bacterium encodes eae and tir genes, which are committed to the production of attaching and effacing lesions. The LEE also contains genes for a type III secretion system $[5,6]$ and for other secretory proteins (esp loci) [5] and pas which is responsible for the secretion of Esp proteins [7]. The large plasmid of STEC O157 also carries several potential virulence determinants characteristic of STEC [8-13]. In addition to EHEC haemolysin which acts as a pore-forming cytolysin of eukaryotic cells $[8,9]$, a bifunctional catalase peroxidase (KatP) [10]

Received 15 Oct. 2001; accepted 28 Nov. 2001.

Corresponding author: Dr H. Nagano (e-mail: nagano@iph. pref.hokkaido.jp). and a human coagulation factor V-cleaving serine protease (EspP) [11] have been identified [12]. The etp gene cluster that presumably encodes a type II secretion pathway system has also been found [13].

In Japan, after relatively large outbreaks of STEC O157:H7 in Okayama and Hiroshima prefectures, in 1996, Sakai city experienced a huge outbreak of STEC O157:H7 when $>5000$ individuals were infected [1416]. Since then, $>1000$ patients have been infected annually with STEC of different serotypes including O157:H7 [15]. In Hokkaido prefecture, before 1996 there were only a few cases of STEC infection, but 1 year later the number of patients infected with STEC O157:H7 increased to 100 .

Unlike other E. coli isolates, STEC O157 isolates are negative for sorbitol fermentation ( $\mathrm{SOR}^{-}$) within $24 \mathrm{~h}$ and do not exhibit $\beta$-D-glucuronidase activity (GUD) $[17,18]$. This enables their efficient differential selection from stool samples on sorbitol-containing MacConkey agar (SMAC) [19], i.e., the colonies of E. coli which are negative for these biochemical activities are most probably STEC O157 [20, 21]. However, in recent years phenotypic variants of non-motile STEC O157, $\mathrm{SOR}^{+}$and $\mathrm{GUD}^{+}$, have been isolated in Germany [22] and the Czech Republic [23], and a motile $\mathrm{SOR}^{-}$and $\mathrm{GUD}^{+}$atypical STEC 0157:H7 strain has been isolated 
in the USA [24]. In particular, Karch et al. [25] reported novel $\mathrm{SOR}^{+}$and $\mathrm{GUD}^{+} \mathrm{O} 157: \mathrm{H}^{-}$strains that caused an outbreak of HUS in Germany and showed their DNA patterns by pulsed-field gel electrophoresis (PFGE) to be unique and distinct from those of typical O157:H7 strains. In Japan also, particularly in Hokkaido, $\mathrm{SOR}^{-}$and $\mathrm{GUD}^{+}$phenotypic variants of STEC O157:H7 have been isolated since 1996. These GUD ${ }^{+}$ STEC 0157:H7 isolates have been examined for their virulence determinants as well as their genetic features by PFGE. Evidence that the $\mathrm{GUD}^{+}$STEC O157:H7 isolates represent a distinct clone within STEC serogroup O157 is presented in this report.

\section{Materials and methods}

\section{Bacterial isolates}

Twenty-two isolates of $\mathrm{GUD}^{+}$STEC O157:H7 were obtained for phenotypic and genotypic studies. Two isolates of typical GUD- STEC O157:H7 from subject numbers 23 and 24 with symptoms of bloody diarrhoea and abdominal cramps were used as controls. The epidemiological data for these isolates are summarised in Table 1. A further 49 typical STEC 0157 isolates (Table 2) from persons with or without clinical symptoms (watery diarrhoea, bloody diarrhoea, abdominal cramps and other signs) and from cattle were subjected to PFGE for dendrogram clustering analysis.

\section{Isolation of enteropathogenic bacteria from stool specimens}

Stool specimens were cultured for bacterial enteric pathogens such as Salmonella, Shigella, Campylobacter, Bacillus, Vibrio, Aeromonas, Plesiomonas and Yersinia spp. by standard procedures [26]. For isolation of E. coli O157, the stool samples were streaked directly on SMAC (Difco) or SMAC supplemented with cefixime (Dynal, Oslo, Norway) $0.05 \mathrm{mg} / \mathrm{L}$ and potassium tellurite (Dynal) $2.5 \mathrm{mg} / \mathrm{L}$ (CT-SMAC), or on both media. On other occasions, stool samples were cultured in $10 \mathrm{ml}$ of GN broth (Merck, Darmstadt, Germany) at $37^{\circ} \mathrm{C}$ for $6 \mathrm{~h}$, followed by mixing $1 \mathrm{ml}$ of the culture with magnetic beads coated with rabbit antiO157 antibodies (Dynal). The magnetic beads were then washed and resuspended in $100 \mu \mathrm{l}$ of a buffer according to the supplier's instructions. One half of the resuspended beads was streaked on to a SMAC plate and the rest on to a CT-SMAC plate. After incubation for $16-20 \mathrm{~h}$ at $37^{\circ} \mathrm{C}$, the resulting $\mathrm{SOR}^{-}$colonies, and a few $\mathrm{SOR}^{+}$colonies, were checked for the presence of the stx gene by PCR. Colonies that gave a positive reaction by PCR were examined further. They were identified as E. coli from their biochemical properties and were serotyped with rabbit anti-O157 and anti-H7 sera (Denkaseiken, Tokyo, Japan).

\section{Phenotypic characterisation of E. coli isolates}

The bacterial isolates were stored on heart infusion agar slants and freshly cultured on SMAC for each test. The biochemical properties of the isolates were examined with the API 20E system (bioMérieux, Marcy l'Etoile, France). The GUD activity of the isolates was examined on three media containing 4methylumbelliferyl- $\beta$-D-glucuronide (MUG): (i) EC medium with MUG (Difco Laboratories), (ii) CLIG agar (Kyokuto seiyaku, Tokyo, Japan) and (iii) Fluorocult $^{\mathrm{TM}}$ E. coli O157:H7-Agar (Merck). An overnight culture at $37^{\circ} \mathrm{C}$ which fluoresced under UV light was judged to be GUD positive. Production of Stx was tested by the reverse passive latex agglutination (RPLA) test according to manufacturer's instructions (Denkaseiken). The haemolytic activity of the isolates was detected after culture on blood agar plates containing defibrinated and washed sheep red blood cells $5 \%$ and $10 \mathrm{mM} \mathrm{CaCl}_{2}[9,27,28]$.

\section{Antimicrobial susceptibility test}

The susceptibility of the isolates to antimicrobial agents was examined by the 'E test' (AB Biodisk, Solna, Sweden).

\section{Standard DNA methods}

E. coli DNA was isolated from $1 \mathrm{ml}$ of an overnight culture with a Wizard Genomic DNA Purification kit (Promega, WI, USA) according to the manufacturer's instructions. The amount of DNA was calculated from its absorption at $260 \mathrm{~nm}$. For regular Southern blot hybridisation, DNA was digested with Bam HI (Toyobo, Tokyo, Japan) and electrophoresed through agarose $0.8 \%$ gels in half-strength Tris-borate-EDTA (TBE) buffer, $\mathrm{pH} 8.3$ [29]. The separated DNA fragments were transferred to Magna nylon membranes (Micron Separation, MA, USA) by standard methods [29]. When checking for clonality of the $\mathrm{GUD}^{+}$STEC O157:H7 isolates, DNA samples in agarose plugs were digested with the restriction endonuclease $X b a \mathrm{I}$, separated by PFGE and transferred to nylon membranes in the same way [29]. Non-radioactive direct DNA labelling and Southern blot hybridisation were performed with a Gene Images AlkPhos Direct labelling and detection kit (Amersham Pharmacia, Uppsala, Sweden) following the manufacturer's procedures. The probes used in this study were prepared by PCR amplification of $s t x_{1}$ (primers LP30/LP31 [30]), stx $x_{2}$ (primers LP43/LP44 [30]), espP (primers esp-A/esp-B [12]) and katP (primers wkat-B/wkat-F [10]).

\section{PCR}

PCR for detecting the specific genes listed in Table 3 was performed with the GeneAmp PCR System 9600 (Perkin-Elmer Applied Biosystems) in a volume of $20 \mu \mathrm{l}$ containing $1 \mu \mathrm{l}$ of purified bacterial DNA 


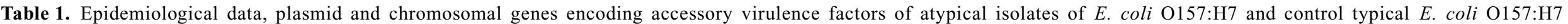
isolates from individuals in Hokkaido, Japan

\begin{tabular}{|c|c|c|c|c|c|c|c|c|c|c|c|c|c|c|c|c|c|c|}
\hline \multirow{3}{*}{$\begin{array}{l}\text { Subject } \\
\text { no. }\end{array}$} & \multirow{3}{*}{$\begin{array}{c}\text { Isolate } \\
\text { no. }\end{array}$} & \multirow{3}{*}{$\begin{array}{l}\text { Age } \\
\text { (years) }\end{array}$} & \multirow[b]{3}{*}{ Sex } & \multirow{3}{*}{$\begin{array}{c}\text { Specimen } \\
\text { collection date }\end{array}$} & \multirow{3}{*}{$\begin{array}{l}\text { City of } \\
\text { isolation }\end{array}$} & \multirow{3}{*}{$\begin{array}{c}\text { Clinical } \\
\text { symptom }\end{array}$} & \multirow[b]{3}{*}{ Serotype } & \multirow{2}{*}{\multicolumn{3}{|c|}{ Phenotype }} & \multirow{2}{*}{\multicolumn{4}{|c|}{ Chromosomal genes* }} & \multicolumn{4}{|c|}{ Plasmid genes $^{\dagger}$} \\
\hline & & & & & & & & & & & & & & & FHEC & & & \\
\hline & & & & & & & & SF & GUD & Haemolysis & $s t x_{I}$ & $s t x_{2}$ & eae & pas & hly & etpD & KatP & espP \\
\hline 1 & EC96012 & 61 & M & Aug. 1996 & Chitose & LF & $\mathrm{O} 157: \mathrm{H} 7$ & $--^{*}$ & + & EHEC-Hly & + & + & $\gamma 1$ & + & + & + & $-1-$ & $-1-$ \\
\hline 2 & EC96020 & 58 & M & Aug. 1996 & Chitose & No & $\mathrm{O} 157: \mathrm{H} 7$ & - & + & EHEC-Hly & + & + & $\gamma 1$ & + & + & + & $-1-$ & $-1-$ \\
\hline 3 & EC96021 & 53 & $\mathrm{~F}$ & Aug. 1996 & Chitose & No & $\mathrm{O} 157: \mathrm{H} 7$ & - & + & EHEC-Hly & + & + & $\gamma 1$ & + & + & + & $-1-$ & $-1-$ \\
\hline 4 & EC96022 & 59 & M & Aug. 1996 & Chitose & No & $\mathrm{O} 157: \mathrm{H} 7$ & - & + & EHEC-Hly & + & + & $\gamma 1$ & + & + & + & $-1-$ & $-1-$ \\
\hline 5 & EC96023 & 50 & M & Aug. 1996 & Chitose & No & $\mathrm{O} 157: \mathrm{H} 7$ & - & + & EHEC-Hly & + & + & $\gamma 1$ & + & + & + & $-1-$ & $-1-$ \\
\hline 6 & EC96024 & 47 & $\mathrm{~F}$ & Aug. 1996 & Chitose & No & $\mathrm{O} 157: \mathrm{H} 7$ & - & + & EHEC-Hly & + & + & $\gamma 1$ & + & + & + & $-1-$ & $-1-$ \\
\hline 8 & EC96026 & 63 & $\mathrm{~F}$ & Aug. 1996 & Chitose & No & $\mathrm{O} 157: \mathrm{H} 7$ & - & + & EHEC-Hly & + & + & $\gamma 1$ & + & + & + & $-1-$ & $-1-$ \\
\hline 9 & EC96027 & 84 & $\mathrm{~F}$ & Aug. 1996 & Chitose & No & O157:H7 & - & + & EHEC-Hly & + & + & $\gamma 1$ & + & + & + & $-1-$ & $-1-$ \\
\hline 10 & EC96029 & 64 & M & Aug. 1996 & Chitose & No & $\mathrm{O} 157: \mathrm{H} 7$ & - & + & EHEC-Hly & + & + & $\gamma 1$ & + & + & + & $-1-$ & $-1-$ \\
\hline 11 & EC96028 & 27 & M & Aug. 1996 & Chitose & No & O157:H7 & - & + & EHEC-Hly & + & + & $\gamma 1$ & + & + & + & $-1-$ & $-1-$ \\
\hline 12 & EC96032 & 2 & $\mathrm{~F}$ & Aug. 1996 & Akkeshi & $\mathrm{D}$ & O157:H7 & - & + & EHEC-Hly & + & + & $\gamma 1$ & + & + & + & $-1-$ & $-1-$ \\
\hline 13 & EC96038 & 26 & $\mathrm{~F}$ & Aug. 1996 & Akkeshi & No & $\mathrm{O} 157: \mathrm{H} 7$ & - & + & EHEC-Hly & + & + & $\gamma 1$ & + & + & + & $-1-$ & $-1-$ \\
\hline 14 & EC96073 & 49 & $\mathrm{~F}$ & Sept. 1996 & Engaru & No & $\mathrm{O} 157: \mathrm{H} 7$ & - & + & EHEC-Hly & + & + & $\gamma 1$ & + & + & + & $-1-$ & $-1-$ \\
\hline 15 & EC96110 & 6 & $\mathrm{~F}$ & Oct. 1996 & Kushiro & $\mathrm{D}$ & $\mathrm{O} 157: \mathrm{H} 7$ & - & + & EHEC-Hly & + & + & $\gamma 1$ & + & + & + & $-1-$ & $-1-$ \\
\hline 16 & EC96111 & 6 & $\mathrm{~F}$ & Oct. 1996 & Kushiro & No & $\mathrm{O} 157: \mathrm{H} 7$ & - & + & EHEC-Hly & + & + & $\gamma 1$ & + & + & + & $-1-$ & $-1-$ \\
\hline 17 & EC96112 & 6 & $\mathrm{~F}$ & Oct. 1996 & Kushiro & No & $\mathrm{O} 157: \mathrm{H} 7$ & - & + & EHEC-Hly & + & + & $\gamma 1$ & + & + & + & $-1-$ & $-1-$ \\
\hline 18 & EC96113 & 4 & M & Oct. 1996 & Kushiro & No & $\mathrm{O} 157: \mathrm{H} 7$ & - & + & EHEC-Hly & + & + & $\gamma 1$ & + & + & + & $-1-$ & $-1-$ \\
\hline 20 & EC97119 & 2 & $\mathrm{~F}$ & Aug. 1997 & Ebetsu & $\mathrm{D}$ & $\mathrm{O} 157: \mathrm{H} 7$ & - & + & EHEC-Hly & + & + & $\gamma 1$ & + & + & + & $-1-$ & $-1-$ \\
\hline 21 & ЕC97120 & 8 & M & Aug. 1997 & Ebetsu & No & O157:H7 & - & + & EHEC-Hly & + & + & $\gamma 1$ & + & + & + & $-1-$ & $-1-$ \\
\hline 22 & EC98206 & 74 & $\mathrm{~F}$ & Oct. 1998 & Kushiro & $\mathrm{D}$ & $\mathrm{O} 157: \mathrm{H} 7$ & - & + & EHEC-Hly & + & + & $\gamma 1$ & + & + & + & $-1-$ & $-1-$ \\
\hline 23 & EC96031 & 23 & $\mathrm{~F}$ & Aug. 1996 & Sapporo & $\mathrm{BD}$ & O157:H7 & - & - & EHEC-Hly & + & + & $\gamma 1$ & + & + & + & $\begin{array}{c}+/ 25.4 \\
\quad 9.0\end{array}$ & $+/ 8.4$ \\
\hline 24 & EC96017 & 8 & M & Aug. 1996 & Obihiro & $\mathrm{BD}$ & $\mathrm{O} 157: \mathrm{H} 7$ & - & - & EHEC-Hly & - & + & $\gamma 1$ & + & + & + & $\begin{array}{c}+/ 25.4 \\
9.0\end{array}$ & $+/ 8.4$ \\
\hline
\end{tabular}


Table 2. E. coli $\mathrm{O} 157$ isolates in Hokkaido examined by PFGE*

\begin{tabular}{|c|c|c|c|c|c|c|c|}
\hline Isolate no. & $\begin{array}{c}\text { Age } \\
\text { (years) }\end{array}$ & Sex & Specimen collection date & City of isolation & $\begin{array}{c}\text { Clinical } \\
\text { symptom }\end{array}$ & Serotype & Stx type \\
\hline EC96004 & 2 & $\mathrm{M}$ & Aug. 1996 & Sapporo & $\mathrm{BD}$ & $\mathrm{O} 157: \mathrm{H} 7$ & $1^{\dagger}$ \\
\hline EC96037 & 9 & M & Aug. 1996 & Chitose & $\mathrm{D}$ & $\mathrm{O} 157: \mathrm{H} 7$ & $1 \& 2$ \\
\hline EC96056 & 7 & $\mathrm{~F}$ & Aug. 1996 & Obihiro & $\mathrm{D}$ & $\mathrm{O} 157: \mathrm{H} 7$ & $1 \& 2$ \\
\hline EC96057 & 2 & $\mathrm{~F}$ & Aug. 1996 & Muroran & $\mathrm{D}$ & $\mathrm{O} 157: \mathrm{H} 7$ & 2 \\
\hline EC96061 & 8 & M & Aug. 1996 & Shikaoi & $\mathrm{BD}$ & $\mathrm{O} 157: \mathrm{H} 7$ & 2 \\
\hline EC96086 & 1 & M & Sept. 1996 & Obihiro & $\mathrm{D}$ & $\mathrm{O} 157: \mathrm{H} 7$ & 2 \\
\hline EC96107 & 4 & M & Oct. 1996 & Obihiro & $\mathrm{D}$ & $\mathrm{O} 157: \mathrm{H} 7$ & 2 \\
\hline EC97005 & 67 & $\mathrm{~F}$ & Jan. 1997 & Sapporo & $\mathrm{D}$ & $\mathrm{O} 157: \mathrm{H} 7$ & $1 \& 2$ \\
\hline EC97026 & 38 & $\mathrm{~F}$ & June 1997 & Kitahiroshima & $\mathrm{D}$ & $\mathrm{O} 157: \mathrm{H} 7$ & $1 \& 2$ \\
\hline EC97032 & 48 & $\mathrm{~F}$ & June 1997 & Sapporo & NS & $\mathrm{O} 157: \mathrm{H} 7$ & 2 \\
\hline EC97090 & 4 & $\mathrm{~F}$ & Aug. 1997 & Obihiro & $\mathrm{BD}$ & $\mathrm{O} 157: \mathrm{H} 7$ & 2 \\
\hline EC97092 & 18 & M & Aug. 1997 & Sapporo & $\mathrm{D}$ & $\mathrm{O} 157: \mathrm{H} 7$ & $1 \& 2$ \\
\hline EC97093 & 18 & M & Aug. 1997 & Engaru & $\mathrm{D}$ & $\mathrm{O} 157: \mathrm{H} 7$ & 2 \\
\hline EC97101 & 1 & $\mathrm{~F}$ & Aug. 1997 & Sapporo & $\mathrm{BD}$ & $\mathrm{O} 157: \mathrm{H} 7$ & $1 \& 2$ \\
\hline EC98147 & 9 & M & Aug. 1998 & Sapporo & $\mathrm{BD}$ & $\mathrm{O} 157: \mathrm{H} 7$ & $1 \& 2$ \\
\hline EC98152 & 21 & $\mathrm{~F}$ & Aug. 1998 & Sapporo & $\mathrm{D}$ & $\mathrm{O} 157: \mathrm{H} 7$ & $1 \& 2$ \\
\hline EC98159 & 5 & M & Aug. 1998 & Makubetsu & $\mathrm{BD}$ & $\mathrm{O} 157: \mathrm{H} 7$ & $1 \& 2$ \\
\hline EC98162 & 21 & $\mathrm{~F}$ & Aug. 1998 & Otofuke & $\mathrm{D}$ & $\mathrm{O} 157: \mathrm{H} 7$ & $1 \& 2$ \\
\hline EC98167 & 2 & M & Aug. 1998 & Iwamizawa & $\mathrm{BD}$ & $\mathrm{O} 157: \mathrm{H}^{-}$ & 2 \\
\hline EC98168 & 65 & $\mathrm{~F}$ & Aug. 1998 & Horonobe & $\mathrm{BD}$ & $\mathrm{O} 157: \mathrm{H} 7$ & $1 \& 2$ \\
\hline EC98166 & 4 & $\mathrm{~F}$ & Sept. 1998 & Tohbetsu & HUS & O157:H7 & 2 \\
\hline EC98187 & 58 & $\mathrm{~F}$ & Sept. 1998 & Kuriyama & $\mathrm{BD}$ & $\mathrm{O} 157: \mathrm{H} 7$ & $1 \& 2$ \\
\hline EC98193 & 2 & M & Sept. 1998 & Noboribetsu & $\mathrm{D}$ & O157:H7 & $1 \& 2$ \\
\hline EC98200 & 12 & M & Sept. 1998 & Iwamizawa & $\mathrm{BD}$ & $\mathrm{O} 157: \mathrm{H} 7$ & $1 \& 2$ \\
\hline EC98221 & 14 & $\mathrm{~F}$ & Oct. 1998 & Asahikawa & $\mathrm{D}$ & $\mathrm{O} 157: \mathrm{H} 7$ & $1 \& 2$ \\
\hline EC98226 & 73 & $\mathrm{M}$ & Oct. 1998 & Yakumo & $\mathrm{BD}$ & O157:H7 & $1 \& 2$ \\
\hline EC99039 & 2 & M & May 1999 & Akabira & $\mathrm{BD}$ & $\mathrm{O} 157: \mathrm{H} 7$ & $1 \& 2$ \\
\hline SREC9901 & 1 & $\mathrm{M}$ & June 1999 & Urakawa & $\mathrm{D}$ & O157:H7 & 2 \\
\hline EC99109 & 9 & $\mathrm{M}$ & July 1999 & Tomakomai & $\mathrm{BD}$ & $\mathrm{O} 157: \mathrm{H} 7$ & $1 \& 2$ \\
\hline EC99120 & 2 & M & July 1999 & Date & $\mathrm{D}$ & $\mathrm{O} 157: \mathrm{H} 7$ & $1 \& 2$ \\
\hline SREC9910 & 14 & $\mathrm{~F}$ & Aug. 1999 & Asahikawa & $\mathrm{D}$ & $\mathrm{O} 157: \mathrm{H} 7$ & $1 \& 2$ \\
\hline SREC9918 & 37 & $\mathrm{M}$ & Sept. 1999 & Sapporo & NS & O157:H7 & 2 \\
\hline SREC9920 & 4 & $\mathrm{~F}$ & Oct. 1999 & Obihiro & $\mathrm{BD}$ & $\mathrm{O} 157: \mathrm{H} 7$ & $1 \& 2$ \\
\hline B342 & NK & $\mathrm{C}$ & Dec. 1999 & Shikaoi & No & $\mathrm{O} 157: \mathrm{H} 7$ & 2 \\
\hline EC00003 & 3 & $\mathrm{~F}$ & Feb. 2000 & Sapporo & $\mathrm{BD}$ & O157:H7 & $1 \& 2$ \\
\hline SREC0003 & 10 & $\mathrm{~F}$ & May 2000 & Otofuke & $\mathrm{BD}$ & $\mathrm{O} 157: \mathrm{H}^{-}$ & $1 \& 2$ \\
\hline EC00044 & 10 & $\mathrm{~F}$ & June 2000 & Bihoro & $\mathrm{D}$ & $\mathrm{O} 157: \mathrm{H} 7$ & 2 \\
\hline EC00064 & 14 & $\mathrm{M}$ & Aug. 2000 & Asahikawa & $\mathrm{BD}$ & O157:H7 & $1 \& 2$ \\
\hline EC00069 & 2 & $\mathrm{M}$ & Aug. 2000 & Makkari & $\mathrm{BD}$ & O157:H7 & $1 \& 2$ \\
\hline EC00101 & 1 & $\mathrm{M}$ & Aug. 2000 & Asahikawa & $\mathrm{BD}$ & O157:H7 & $1 \& 2$ \\
\hline SREC0021 & 73 & $\mathrm{~F}$ & Aug. 2000 & Asahikawa & $\mathrm{BD}$ & $\mathrm{O} 157: \mathrm{H} 7$ & $1 \& 2$ \\
\hline B497 & NK & $\mathrm{C}$ & Aug. 2000 & Shikaoi & No & O157:H7 & 2 \\
\hline EC00098 & 31 & $\mathrm{M}$ & Sept. 2000 & Eniwa & $\mathrm{D}$ & $\mathrm{O} 157: \mathrm{H} 7$ & $1 \& 2$ \\
\hline B539 & NK & $\mathrm{C}$ & Dec. 2000 & Shintoku & No & O157:H7 & 2 \\
\hline B515 & $\mathrm{NK}$ & $\mathrm{C}$ & Dec. 2000 & Kushiro & No & $\mathrm{O} 157: \mathrm{H} 7$ & 2 \\
\hline
\end{tabular}

Abbreviations used in this table are the same as those in Table 1 except $\mathrm{C}$ (cattle) and NK (not known).

* All O157 isolates listed here did not ferment sorbitol within $24 \mathrm{~h}$ on SMAC and had the GUD ${ }^{-}$phenotype.

${ }^{\dagger}$ Isolate was stx $x_{1}$ and $s t x_{2}$ positive by PCR but production of Stx 2 was not observed by RPLA test.

(c. $200 \mathrm{ng}$ ), $200 \mathrm{mM}$ deoxynucleotide triphosphates (dATP, dCTP, dGTP and dTTP), 30 pmol of each primer, $2 \mu \mathrm{l}$ of a 10 -fold concentrated buffer mixture and $2.5 \mathrm{U}$ of Taq polymerase (Takara). The PCR conditions, primer designations and sequences are given in Table 3.

\section{DNA fingerprint analysis by $P F G E$}

PFGE analysis was conducted according to the methods described previously [14] but with a slight modification. Agarose plugs containing bacterial cells were incubated in $0.5 \mathrm{ml}$ of lysis buffer containing lysozyme $5 \mathrm{mg} / \mathrm{ml}, 0.5 \mathrm{M}$ EDTA ( $\mathrm{pH} 8.0$ ) at $37^{\circ} \mathrm{C}$ for $3 \mathrm{~h}$. After incubation, the lysis buffer was removed and $0.5 \mathrm{ml}$ of proteinase buffer - $0.5 \mathrm{M}$ EDTA, $\mathrm{pH}$ 8.0, sodium sarkosyl $1 \%$ containing proteinase $\mathrm{K}$ (Roche Diagnostics, Mannheim, Germany) $1 \mathrm{mg} / \mathrm{ml} \mathrm{-} \mathrm{was} \mathrm{added} \mathrm{to}$ the plugs, followed by incubation at $50^{\circ} \mathrm{C}$ for $18-24 \mathrm{~h}$. Proteinase activity was stopped by adding $1 \mathrm{ml}$ of $4 \mathrm{mM}$ PefablocSC (Roche) in TE buffer (10 mM Tris$\mathrm{HCl}$ and $1 \mathrm{mM}$ EDTA, pH 8.0). The genomic DNA in the agarose plugs was digested with XbaI (Takara) following the conditions indicated by the manufacturer. The resulting DNA fragments were electrophoresed through agarose $1 \%$ with the CHEF-DRIII apparatus (BioRad Laboratories, Richmond, CA, USA) at $6 \mathrm{~V} / \mathrm{cm}$ and $14^{\circ} \mathrm{C}$ for $22 \mathrm{~h}$ with switch times ranging from 4 to $50 \mathrm{~s}$. $\lambda$ Concatamers (BioRad) were used as DNA size markers. After staining with ethidium 
Table 3. PCR primers used and PCR conditions

\begin{tabular}{|c|c|c|c|c|c|c|c|}
\hline \multirow{2}{*}{$\begin{array}{l}\text { Primer } \\
\text { designation }\end{array}$} & \multirow[b]{2}{*}{ Nucleotide sequence $\left(5^{\prime}-3^{\prime}\right)$} & \multirow[b]{2}{*}{ Target } & \multicolumn{3}{|c|}{ PCR conditions* } & \multirow{2}{*}{$\begin{array}{l}\text { PCR product } \\
\text { size (bp) }\end{array}$} & \multirow[b]{2}{*}{ Referenc } \\
\hline & & & Denature & Annealing & Extension $^{\dagger}$ & & \\
\hline LP30 & CAG TTA ATG TGG TGG CGA AGG & $s t x_{1}$ & $94^{\circ} \mathrm{C}, 90 \mathrm{~s}$ & $64^{\circ} \mathrm{C}, 90 \mathrm{~s}$ & $72^{\circ} \mathrm{C}, 90 \mathrm{~s}$ & 348 & 30 \\
\hline LP31 & CAC CAG ACA ATG TAA CCG CTG & & & & & & \\
\hline LP43 & ATC CTA TTC CCG GGA GTT TAC G & $s t x_{2}$ & $94^{\circ} \mathrm{C}, 90 \mathrm{~s}$ & $64^{\circ} \mathrm{C}, 90 \mathrm{~s}$ & $72^{\circ} \mathrm{C}, 90 \mathrm{~s}$ & 584 & 30 \\
\hline LP44 & GCG TCA TCG TAT ACA CAG GAG C & & & & & & \\
\hline PT-2 & GCG AAA ACT GTG GAA TTG GG & uidA & $94^{\circ} \mathrm{C}, 90 \mathrm{~s}$ & $64^{\circ} \mathrm{C}, 90 \mathrm{~s}$ & $72^{\circ} \mathrm{C}, 90 \mathrm{~s}$ & 252 & 30 \\
\hline PT-3 & TGA TGC TCC ATA ACT TCC TG & & & & & & \\
\hline SK1 & CCC GAA TTC GGC ACA AGC ATA AGC & eae (SK1/SK2) & $94^{\circ} \mathrm{C}, 30 \mathrm{~s}$ & $62^{\circ} \mathrm{C}, 60 \mathrm{~s}$ & $72^{\circ} \mathrm{C}, 90 \mathrm{~s}$ & 881 & 32 \\
\hline SK2 & CCC GGA TCC GTC TCG CCA GTA TTC G & & & & & & \\
\hline LP2 & CCC GAA TTC TTA TTT TAC ACA AGT GGC & eae $\alpha(\mathrm{SK} 1 / \mathrm{LP} 2)$ & $94^{\circ} \mathrm{C}, 30 \mathrm{~s}$ & $62^{\circ} \mathrm{C}, 60 \mathrm{~s}$ & $72^{\circ} \mathrm{C}, 90 \mathrm{~s}$ & 2807 & 32 \\
\hline LP3 & CCC GAA TTC TTA TTC TAC ACA AAC CGC & eae $\gamma(\mathrm{SK} 1 / \mathrm{LP} 3)$ & $94^{\circ} \mathrm{C}, 30 \mathrm{~s}$ & $62^{\circ} \mathrm{C}, 60 \mathrm{~s}$ & $72^{\circ} \mathrm{C}, 90 \mathrm{~s}$ & 2792 & 32 \\
\hline LP4 & CCC GTG ATA CCA GTA CCA ATT ACG GTC & eae $\beta$ (SK1/LP4) & $94^{\circ} \mathrm{C}, 30 \mathrm{~s}$ & $62^{\circ} \mathrm{C}, 60 \mathrm{~s}$ & $72^{\circ} \mathrm{C}, 90 \mathrm{~s}$ & 2287 & 32 \\
\hline LP5 & AGC TCA CTC GTA GAT GAC GGC AAG CG & eae $\varepsilon(\mathrm{SK} 1 / \mathrm{LP} 5)$ & $94^{\circ} \mathrm{C}, 30 \mathrm{~s}$ & $62^{\circ} \mathrm{C}, 60 \mathrm{~s}$ & $72^{\circ} \mathrm{C}, 90 \mathrm{~s}$ & 2608 & 32 \\
\hline wkat-B & CTT CCT GTT CTG ATT CTT CTG G & katP & $94^{\circ} \mathrm{C}, 30 \mathrm{~s}$ & $56^{\circ} \mathrm{C}, 60 \mathrm{~s}$ & $72^{\circ} \mathrm{C}, 150 \mathrm{~s}$ & 2125 & 10 \\
\hline wkat-F & AAC TTA TTT CTC GCA TCA TCC & & & & & & \\
\hline hlyA1 & GGT GCA GCA GAA AAA GTT GTA G & hlya & $94^{\circ} \mathrm{C}, 30 \mathrm{~s}$ & $57^{\circ} \mathrm{C}, 60 \mathrm{~s}$ & $72^{\circ} \mathrm{C}, 90 \mathrm{~s}$ & 1551 & 8 \\
\hline hlyA4 & TCT CGC CTG ATA GTG TTT GGT A & & & & & & \\
\hline D1 & CGT CAG GAG GAT GTT CAG & $\operatorname{etp} D$ & $94^{\circ} \mathrm{C}, 30 \mathrm{~s}$ & $52^{\circ} \mathrm{C}, 60 \mathrm{~s}$ & $72^{\circ} \mathrm{C}, 70 \mathrm{~s}$ & 1062 & 13 \\
\hline D13R & CGA CTG CAC CTG TTC CTG ATT A & & & & & & \\
\hline esp-A & AAA CAG CAG GCA CTT GAA CG & $\operatorname{esp} P$ & $94^{\circ} \mathrm{C}, 30 \mathrm{~s}$ & $56^{\circ} \mathrm{C}, 60 \mathrm{~s}$ & $72^{\circ} \mathrm{C}, 150 \mathrm{~s}$ & 1830 & 12 \\
\hline esp-B & GGA GTC GTC AGT CAG TAG AT & & & & & & \\
\hline ANK49 & GCA GGA TCC ATG TTA TCC TCA TAT AAA ATA AAC & pas & $94^{\circ} \mathrm{C}, 30 \mathrm{~s}$ & $56^{\circ} \mathrm{C}, 60 \mathrm{~s}$ & $72^{\circ} \mathrm{C}, 150 \mathrm{~s}$ & 1239 & 7 \\
\hline ANK50 & CCA GGT ACC TTA ATA CGA CAG TGG AAT ATG & & & & & & \\
\hline
\end{tabular}

*For 30 cycles.

†After 30 cycles, final extension step was done for $5 \mathrm{~min}$. 
bromide, the agarose gel was photographed and the band image was digitised for computer analysis. The GelCompar software package (Applied Maths, Kortrijk, Belgium) was used for cluster analysis. For further analysis of the clonal structure of these atypical $\mathrm{GUD}^{+}$ STEC O157:H7 isolates, genomic DNA was digested with NotI, SfiI, SpeI and SwaI restriction endonucleases (Takara). For the PFGE analyses of digests with these enzymes, switch times and electrophoresis times were modified: for Not I and SpeI digests, the switch time was $4-8 \mathrm{~s}$ for $9 \mathrm{~h}$ followed by $8-50 \mathrm{~s}$ for $13 \mathrm{~h}$; and for Sfi I and SwaI digests, the switch time was 2 $20 \mathrm{~s}$ for $22 \mathrm{~h}$.

\section{Results}

Isolation of $G U D^{+}$E. coli O157:H7 strains and their epidemiological background in Hokkaido

A total of 22 isolates of $\mathrm{GUD}^{+}$E. coli $\mathrm{O} 157: \mathrm{H} 7$ was obtained from two outbreaks and four sporadic cases that occurred between Aug. 1996 and Oct. 1998 as listed in Table 1. The isolates were obtained from the residents of six cities in Hokkaido (Fig. 1). The first outbreak occurred in the psychiatric ward of a hospital in Chitose city, producing 10 isolates from 163 inpatients (subject nos 1-10) and one isolate from 108 staff members (subject no. 11). The second outbreak occurred in a kindergarten in Kushiro city, producing four isolates from 41 children (subject nos 15-18).

The first sporadic case in a kindergarten in Akkeshi city produced two isolates: one from an infant (subject no. 12) and the other from the teacher (subject no. 13). In the second sporadic case in Asahikawa city, one isolate was obtained from a 22-year-old woman with loose stools (subject no. 19). In the third sporadic case in Ebetsu city, two isolates were obtained from siblings; one had loose stools (subject no. 20) and the other had no symptoms (subject no. 21). In the fourth sporadic case in Kushiro city, one isolate was obtained from a 74-year-old man with loose stools (subject no. 22). Lastly, one isolate was obtained from a healthy woman in Engaru (subject no. 14). In total, six persons passed loose stools or had diarrhoea but none of them had bloody stools or abdominal cramps. They received antibiotic therapy for a few days and they were cured shortly afterwards. Sixteen persons were completely asymptomatic. No other enteric pathogens were identified in the 22 stool specimens.

\section{Biochemical properties of the $G U D^{+}$E. coli O157:H7 isolates}

All 22 of these E. coli $\mathrm{O} 157: \mathrm{H} 7$ isolates produced GUD after incubation for 16-24 h. However, none of them had rhamnose fermentation activity as shown by API 20E. No other differences in biochemical activities were seen between the $\mathrm{GUD}^{+}$and $\mathrm{GUD}^{-}$isolates of STEC O157.

\section{Detection of accessory virulence genes}

PCR reactions were performed to detect virulence genes in the atypical GUD ${ }^{+}$E. coli $\mathrm{O} 157: \mathrm{H} 7$ isolates. As shown in Table 1, in all the isolates, fragments of EHEC-hlyA, etpD, stx $1, s t x_{2}$ and pas genes were amplified by each specific primer to the same predicted sizes as for the typical GUD- STEC O157:H7 isolates. However, katP and espP sequences that are usually

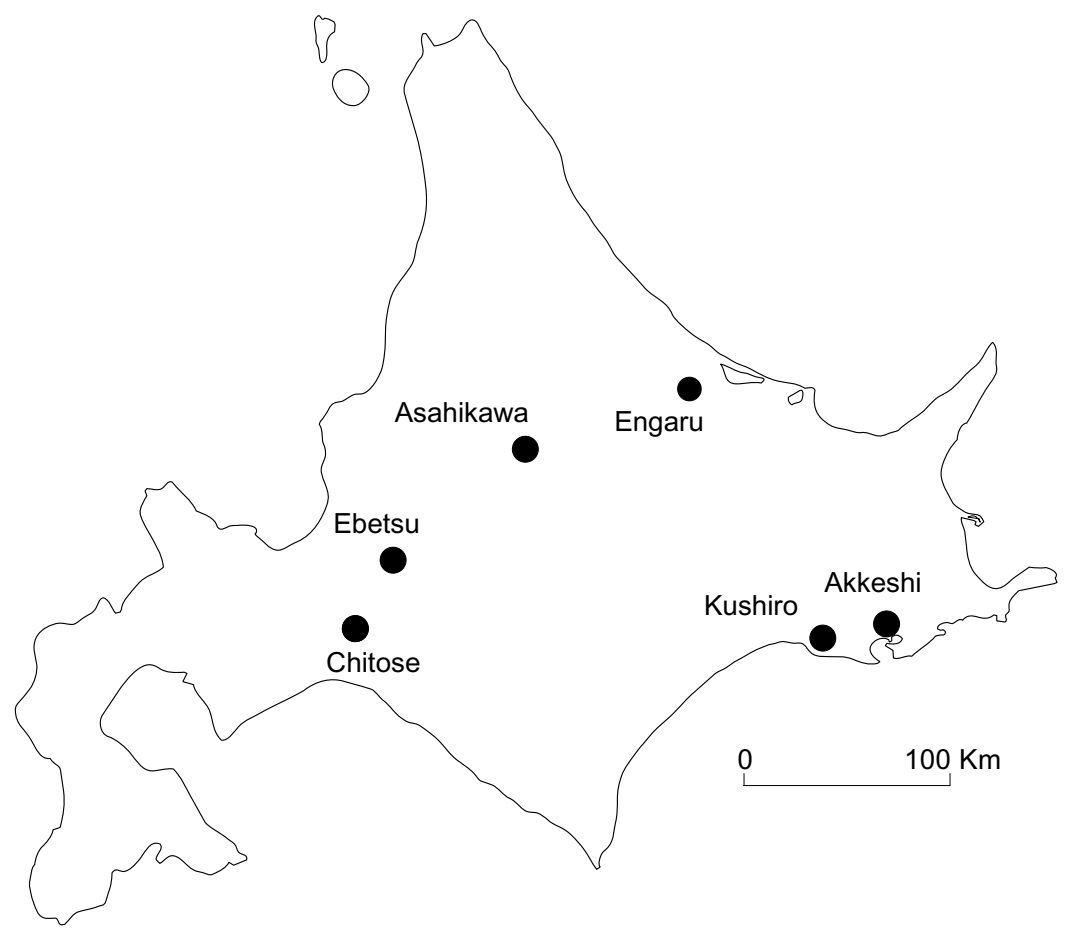

Fig. 1. Locations of the cities where the $\mathrm{GUD}^{+}$STEC O157:H7 isolates were obtained. 
detected in typical GUD ${ }^{-}$STEC O157:H7 isolates were not detectable in the $\mathrm{GUD}^{+}$STEC O157:H7 isolates obtained in Hokkaido. To confirm this, blots of Bam HI-restricted DNA of these isolates were hybridised with either katP or espP DNA fragments. As shown in Table 1, none of the isolates produced signals for katP or espP, whereas the $\mathrm{GUD}^{-}$control isolates EC96017 and EC96031 DNA gave positive signals at 25.4 plus $9.0 \mathrm{~kb}(\mathrm{~kat} P)$ and $8.4 \mathrm{~kb}($ esp $P$ ) positions on the Bam HI blot.

For identification of the eaeA gene, PCR amplification was conducted initially with primers SK1 and SK2 [31]. Later, additional primers (SK1/LP2, SK1/LP3, SK1/LP4 and SK1/LP5) were used to determine the subclass of intimin which is encoded by this gene [31]. Of these primer sets, only SK1/LP3 produced 2972-bp DNA fragments, which were cleaved with $P v u$ II to give the specific restriction fragment length polymorphism (RFLP) patterns reported by Oswald et al. [31]. This indicated that the $\mathrm{GUD}^{+}$STEC O157:H7 isolates possessed a $\gamma 1$ type intimin gene similar to that of the GUD $^{-}$STEC O157:H7 isolates (Table 1).

\section{Phenotypic characteristics in $G U D^{+}$STEC O157:H7 isolates}

Phenotypic determinants were characterised and are shown in Table 1. Stx production was confirmed by the RPLA test. All the GUD ${ }^{+}$STEC O157:H7 isolates produced Stx 1 and Stx2. These isolates also produced enterohaemolysin on blood agar but were unable to ferment sorbitol on SMAC agar plates within $24 \mathrm{~h}$.

\section{Antimicrobial susceptibility testing}

All the atypical GUD ${ }^{+}$STEC O157:H7 isolates showed very similar antimicrobial susceptibility patterns. Differences in MIC values to each antimicrobial agent were no more than two-fold among the isolates and they were judged susceptible to the antimicrobial agent used (Table 4).

\section{PFGE analysis}

The $X b a$ I digestion patterns of the $11 \mathrm{GUD}^{+}$STEC O157:H7 isolates from the outbreak in the psychiatric ward of a hospital in Chitose are shown in Fig. 2. They were identical to one another as regards the number and size of the $X b a \mathrm{I}$ DNA fragments, indicating a clonal origin. The $X b a \mathrm{I}$ digestion patterns of the four $\mathrm{GUD}^{+}$STEC O157:H7 isolates from the outbreak in the kindergarten in Kushiro were identical as shown in Fig. 3 (lanes 15, 16 and 18) or almost identical (lane 17) to one another and were essentially the same as those of the isolates from Chitose city (lane 1). The $X b a \mathrm{I}$ digestion patterns of the isolates from the sporadic cases in Akkeshi city (lanes 12 and 13), Engaru city (lane 14), Asahikawa city (lane 19), Ebetsu city (lanes 20 and 21) and Kushiro city (lane 22) were very similar to those of the isolates from Chitose city (lane 1). The differences among these $X b a \mathrm{I}$ digestion patterns were less than two DNA fragments [32]. Thus, the identical or closely similar $X b a \mathrm{I}$ digestion patterns

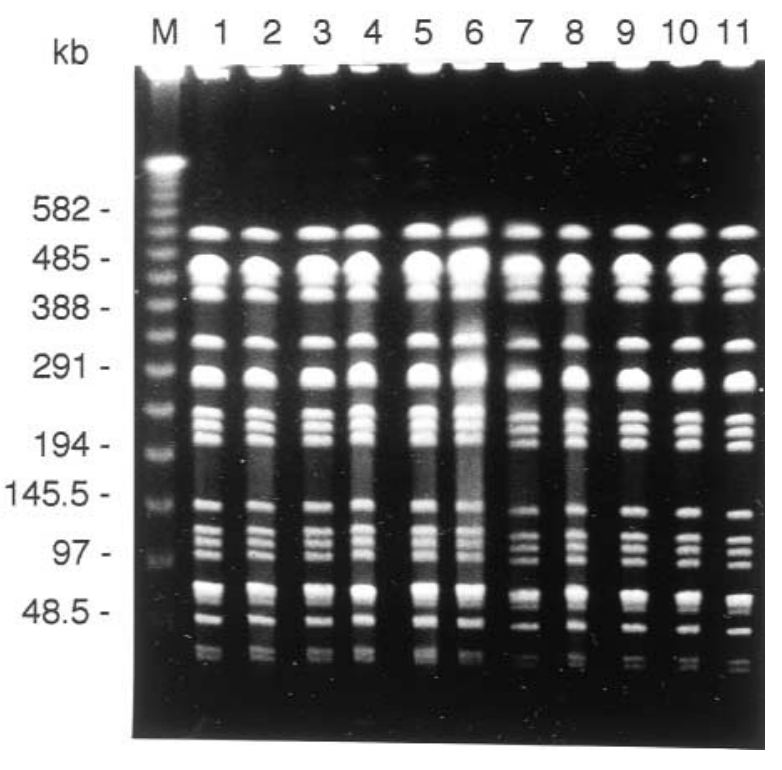

Fig. 2. XbaI-digested genomic DNA from $\mathrm{GUD}^{+}$STEC O157:H7 isolates from in-patients (lanes 1-10) and a staff member (11) on the psychiatric ward of a hospital in Chitose city. Lane $\mathbf{M}$, mol. wt marker of $\lambda$ DNA concatamers.

Table 4. Comparison of antimicrobial susceptibility patterns of $\mathrm{GUD}^{+}$and GUD $^{-}$STEC O157:H7 isolates

\begin{tabular}{lccc}
\hline & \multicolumn{3}{c}{ MIC $(\mu \mathrm{g} / \mathrm{ml})$ for isolates } \\
\cline { 2 - 4 } Antimicrobial agent & $\mathrm{GUD}^{+*}$ & $\mathrm{EC} 96031\left(\mathrm{GUD}^{-}\right)$ & $\mathrm{EC} 96017\left(\mathrm{GUD}^{-}\right)$ \\
\hline Ampicillin & $2-4(\mathrm{~S})$ & $2(\mathrm{~S})$ & $2(\mathrm{~S})$ \\
Cefotaxime & $0.032-0.064(\mathrm{~S})$ & $0.064(\mathrm{~S})$ & $0.047(\mathrm{~S})$ \\
Gentamicin & $0.5-1(\mathrm{~S})$ & $0.25(\mathrm{~S})$ & $0.25(\mathrm{~S})$ \\
Ciprofloxacin & $0.008-0.016(\mathrm{~S})$ & $0.016(\mathrm{~S})$ & $0.016(\mathrm{~S})$ \\
Norfloxacin & $0.064(\mathrm{~S})$ & $0.125(\mathrm{~S})$ & $0.125(\mathrm{~S})$ \\
Tetracycline & $0.5-1(\mathrm{~S})$ & $2(\mathrm{~S})$ & $1(\mathrm{~S})$ \\
Sulphamethoxazole-trimethoprim & $0.032(\mathrm{~S})$ & $0.032(\mathrm{~S})$ & $0.032(\mathrm{~S})$ \\
Trimethoprim & $0.125(\mathrm{~S})$ & $0.125(\mathrm{~S})$ & $0.125(\mathrm{~S})$ \\
Fosfomycin & $0.5-1(\mathrm{~S})$ & $1(\mathrm{~S})$ & $0.5(\mathrm{~S})$ \\
Chloramphenicol & $2-4(\mathrm{~S})$ & $4(\mathrm{~S})$ & $6(\mathrm{~S})$ \\
\hline
\end{tabular}

S, susceptible.

* MIC of $22 \mathrm{GUD}^{+}$isolates. 


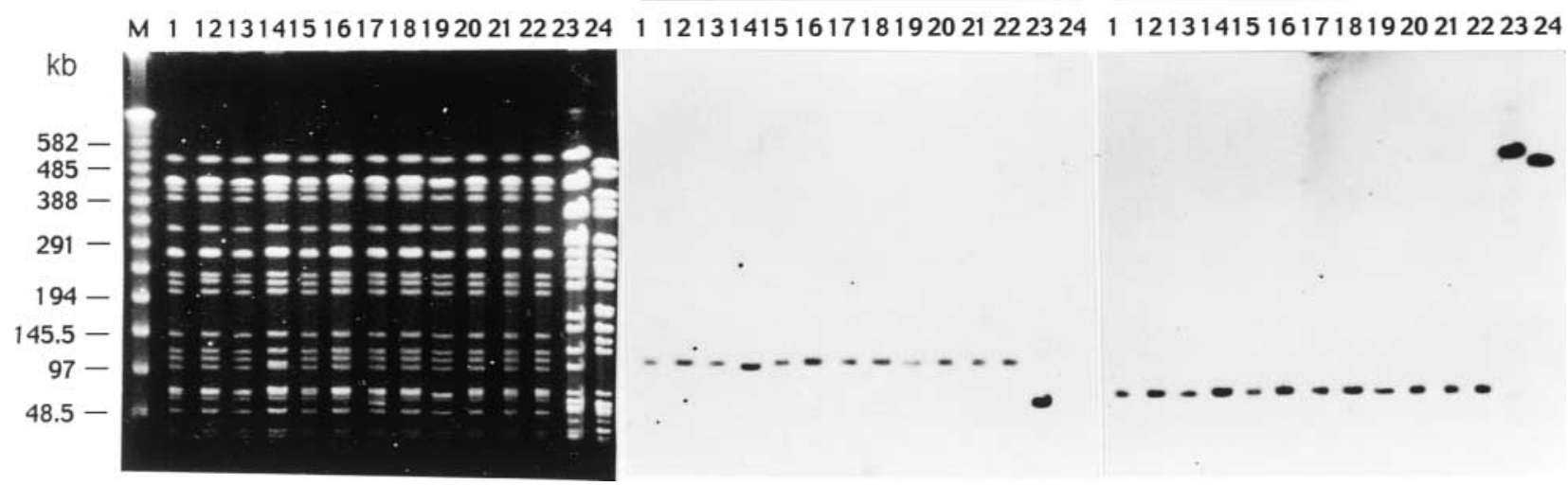

Fig. 3. PFGE patterns of $X b a$ I-digested genomic DNA from GUD ${ }^{+}$STEC O157:H7 isolates from Chitose city (lane 1), Akkeshi city (12, infant; 13, teacher), Engaru city (14), Kushiro city (15-18), Asahikawa city (19), Ebetsu city (20, 21) and Kushiro city (22). Control GUD ${ }^{-}$STEC O157:H7 isolate digests are in lanes 23 (EC96031) and 24 (EC96017). Lane M, mol. wt marker of $\lambda$ DNA concatamers. The separated $X b a$ I restriction DNA fragments were blotted on to nylon membrane and probed with PCRamplified $s t x_{1}$ and $s t x_{2}$ products. Labelling of the probe DNA, hybridisation with the blotted DNA and visualisation of the signals were performed according to the manufacturer's instructions (Gene Images AlkPhos Direct labelling and detection kit: Amersham Pharmacia, Uppsala, Sweden).

of the 22 isolates of $\mathrm{GUD}^{+}$STEC O157:H7 indicated that they belong to a single clone. For further confirmation of this clonality, PFGE analysis was repeated on these $\mathrm{GUD}^{+}$STEC O157:H7 isolates after digestion with the restriction endonucleases Not $\mathrm{I}$, Swa I, Sfi I and SpeI. As shown in Fig. 4, the difference in each of the PFGE patterns among the isolates was four bands or less. The blot of PFGE-separated chromosomal DNAs of these isolates was also probed with the PCR products of $s t x_{1}$ and $s t x_{2}$. The $X b a \mathrm{I}$ restriction fragments of $110 \mathrm{~kb}$ and $80 \mathrm{~kb}$ were shown to contain DNA sequences homologous to $s t x_{1}$ and $s t x_{2}$, respectively (Fig. 3). This provided further evidence of the high degree of clonality of the isolates.

The XbaI-restricted PFGE patterns of the 51 GUD $^{-}$ STEC O157 isolates from individuals with symptoms of watery diarrhoea (19 isolates), bloody diarrhoea (24), HUS (1) or with no symptoms (3) and from cattle (4) were compared with these of the $\mathrm{GUD}^{+}$STEC O157:H7 isolates. A dendrogram of the PFGE patterns was constructed with GelCompar software and is depicted in Fig. 5. The GUD ${ }^{+}$STEC O157:H7 isolates formed a cluster distinct from the other typical STEC O157. They showed similarities of $\geqslant 91.9 \%$ within the $\mathrm{GUD}^{+}$STEC O157:H7 cluster, but only 59.7\% similarity with the closest other cluster. These results showed that $\mathrm{GUD}^{+}$STEC $\mathrm{O} 157$ isolates made a unique clone among the STEC O157 complex.

\section{Discussion}

This report provides evidence that $22 \mathrm{GUD}^{+}$STEC O157:H7 isolates from Hokkaido, Japan obtained during 1996-1998 make a distinct clonal subgroup within the $\mathrm{O} 157$ complex. PFGE analyses with several restriction endonucleases revealed that the isolates were closely related to one another. They showed similar antimicrobial susceptibility patterns and retained a large plasmid that carried etpD and EHEC-hlyA genes but, unlike typical $\mathrm{GUD}^{-}$STEC O157, had lost espP and katP genes. They also exhibited the same phenotypes of virulence determinants such as production of Stx1, Stx2 and enterohaemolysin. To our knowledge, this is the first report of the isolation of well-characterised $\mathrm{GUD}^{+}$STEC O157:H7 strains in Japan.

These atypical STEC O157:H7 isolates were shown to possess some interesting characteristics in addition to $\mathrm{GUD}^{+}$activity. STEC strains produce several virulence factors responsible for the clinical symptoms distinctive to the infected person. Some of the factors are coded in the chromosomal DNA and the others in plasmid DNA [5-13]. There is a locus in the chromosomal DNA containing a cluster of genes for the expression of specific pathogenicity, called attaching-and-effacing (A/ E) histopathology, which was first found in enteropathogenic E. coli (EPEC) strain E2348/69 and named LEE [33]. To obtain more information on the pathogenicity of the STEC isolates, the type of eaeA gene and the presence of the pas gene in STEC O157:H7 were examined. All the GUD ${ }^{+}$STEC O157:H7 isolates had the pas gene and were shown to possess the eaeA gene coding for $\gamma 1$ type intimin, as do the typical GUD ${ }^{-}$STEC 0157 strains. Thus, chromosome-encoded virulence factors could not discriminate the $\mathrm{GUD}^{+}$ STEC O157:H7 isolates from the GUD- STEC O157 strains.

In general, plasmid DNA encodes various virulence factors in enteropathogenic bacteria such as EPEC, enterotoxigenic $E$. coli and enteroinvasive $E$. coli as well as STEC. The STEC have been characterised in terms of a large plasmid of $93.6-104 \mathrm{~kb}$ [34], designated pO157 [35]. pO157 is reported to have heterogeneity with respect to gene composition and 
a

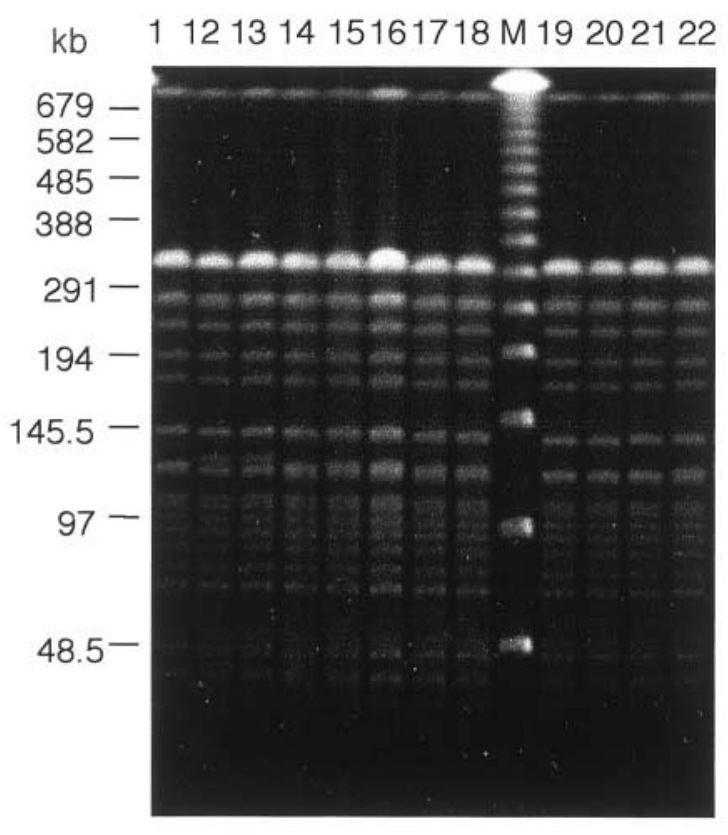

C

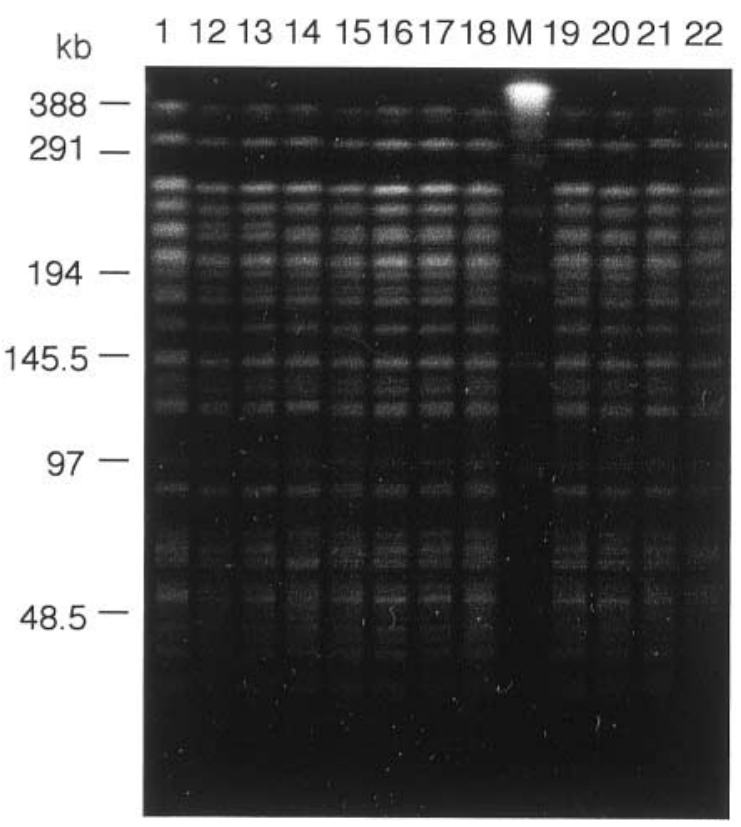

$\mathrm{b}$
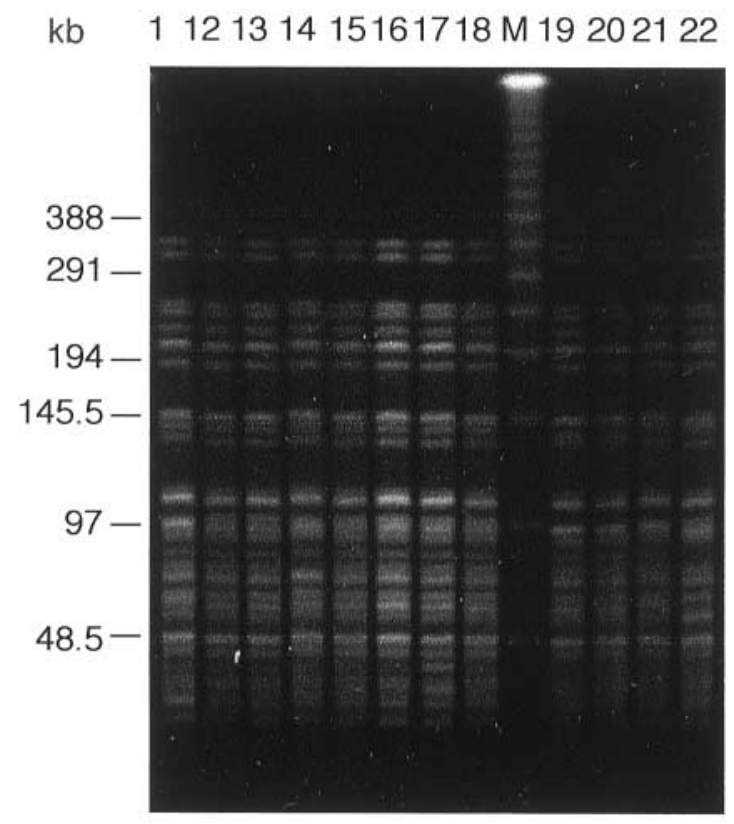

d

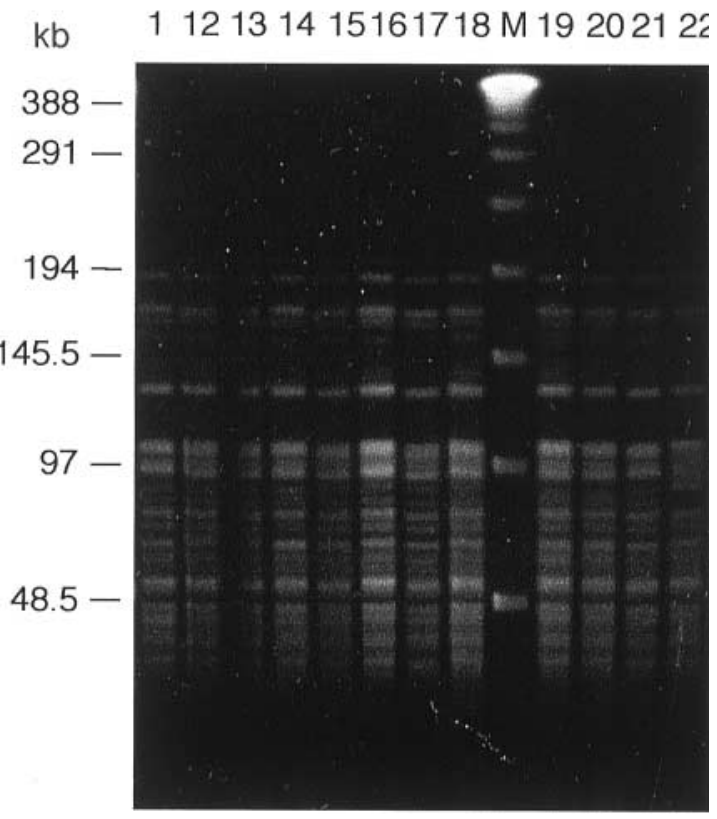

Fig. 4. PFGE patterns of the DNA of GUD ${ }^{+}$STEC O157:H7 isolates from Hokkaido digested with Not I (a), SpeI (b), SfiI (c), and $S w a \mathrm{I}$ (d). Lane M, mol. wt marker of $\lambda$ DNA concatamers. Lane numbers correspond to the subject numbers shown in Table 1.

arrangement among different serotypes of STEC [12]. In Germany and the Czech Republic, some GUD ${ }^{+}$ STEC O157: $\mathrm{H}^{-}$strains have been isolated from patients suffering from HUS and diarrhoea. Fingerprinting analysis indicated that these isolates belonged to a distinct clone in the STEC O157 complex $[23,25]$. However, Bielaszewska et al. [36] described two types of large plasmid present in $\mathrm{SOR}^{+}$and $\mathrm{GUD}^{+}$STEC O157 strains in Europe: one type possessed a combination of EHEC-hlyA and etpD but not katP nor espP genes, whereas the other type contained none of these four genes. The virulence gene profile of the large plasmid in the $\mathrm{GUD}^{+}$STEC O157:H7 isolates from Hokkaido corresponded to the former type of plasmid described above. The present study failed to find heterogeneity in the pO157 of GUD ${ }^{+}$STEC O157, suggesting a high degree of clonality in the GUD ${ }^{+}$ STEC 0157:H7 isolates. There were further properties that distinguished between the European GUD ${ }^{+}$STEC O157 isolates and those from Hokkaido: the isolates from Hokkaido were motile, did not ferment sobitol within $24 \mathrm{~h}$ and produced both Stx1 and Stx2, whereas 
Similarity (\%)

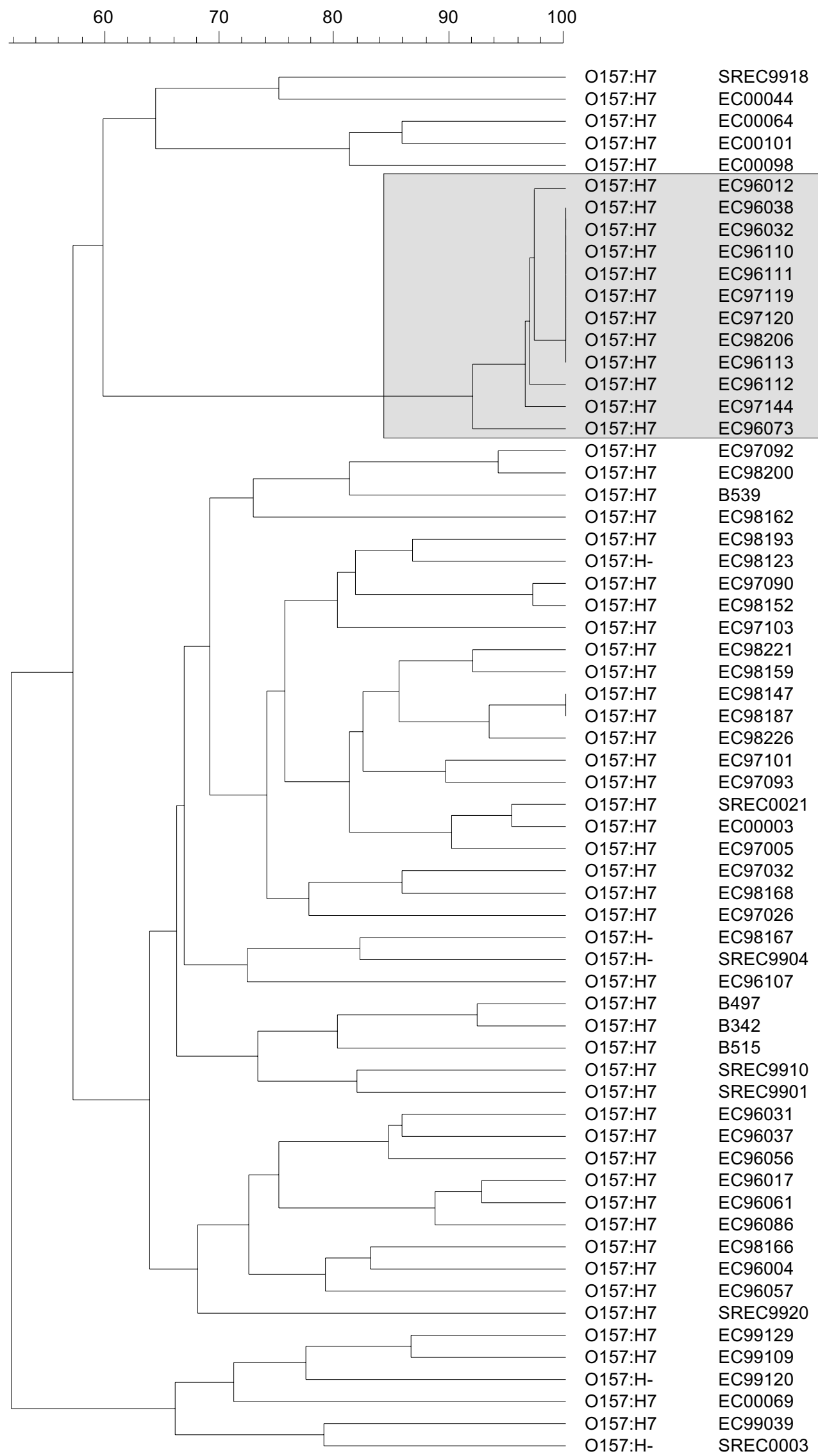

Fig. 5. Dendrogram derived from similarities by PFGE of $X b a$ I-digested DNA for Hokkaido GUD ${ }^{+}$and GUD $^{-}$STEC O157 isolates with GelCompar software package. The characteristics of the isolates are given in Tables 1 and 2 . The GUD ${ }^{+}$STEC $\mathrm{O} 157: \mathrm{H} 7$ isolates are clustered in the shaded box. 
the European isolates produced only Stx2, were nonmotile and fermented sorbitol within $24 \mathrm{~h}$.

$\mathrm{SOR}^{+}$and $\mathrm{GUD}^{+}$STEC O157: $\mathrm{H}^{-}$strains in Europe have been isolated from patients with bloody diarrhoea or HUS, whereas the GUD ${ }^{+}$STEC O157:H7 isolates in Hokkaido were from individuals without HUS. Moreover, of 22 residents shedding $\mathrm{GUD}^{+}$STEC O157, 16 people $(72.7 \%)$ were symptomless. The manifestation of clinical symptoms seems to be dependent on the patient's age [37]. Of the persons infected with STEC O157, $82 \%$ of those aged $<10$ years ( 475 of 576$)$ and $68 \%$ of those aged $>70$ years ( 47 of 69 ) showed one or more symptoms. In contrast to this, examination of the 22 persons infected with the GUD ${ }^{+}$STEC O157:H7 isolates revealed that only $43 \%$ of those aged $<10$ years (3 of 7) and 33\% of those aged $>70$ years ( 1 of 3) manifested clinical symptoms (Table 1). These epidemiological data suggest that the $\mathrm{GUD}^{+}$STEC O157:H7 isolates cause mild symptoms, if any, in young and old patients who are thought to be the most susceptible.

At present, increasing numbers of healthy people are carriers of STEC strains and are probably the source of many sporadic infections. In contrast to the European $\mathrm{SOR}^{+}$and $\mathrm{GUD}^{+}$STEC O157:H $\mathrm{H}^{-}$strains, the $\mathrm{GUD}^{+}$ STEC O157:H7 isolates from Hokkaido produced enterohaemolysin and grew on CT-SMAC like the typical STEC 0157 strains. Therefore, these $\mathrm{GUD}^{+}$ STEC O157:H7 strains can be isolated from stool samples as easily as the typical STEC O157 strains $[36,38]$.

It is well known from PFGE analysis that STEC O157 strains have many genotypes [14]. We have also observed genome diversity in typical GUD ${ }^{-}$STEC O157 strains in Hokkaido. By contrast, the $\mathrm{SOR}^{+}$and $\mathrm{GUD}^{+}$STEC O157: $\mathrm{H}^{-}$isolates from Germany and the Czech Republic displayed very similar PFGE patterns $[25,36]$. In the same way, PFGE analysis showed that the $\mathrm{GUD}^{+}$STEC O157:H7 isolates from Hokkaido were more closely related to one another than to the typical GUD ${ }^{-}$STEC O157 (Fig. 4). There was no known link between any of these outbreaks and the sporadic cases. The clonal nature of the $\mathrm{GUD}^{+}$STEC O157:H7 isolates seems to indicate that either the strains have evolved independently to one very similar clone or they originated from the same clone. Recently, it was reported that the atypical $\mathrm{SOR}^{+}$and $\mathrm{GUD}^{+}$ STEC O157: $\mathrm{H}^{-}$strain isolated in the Czech Republic was also isolated from cattle [36]. Similarly, a wild deer captured in Hokkaido, Japan, was found to carry almost the same GUD ${ }^{+}$STEC O157:H7 strain as those reported here (unpublished data). It is conceivable that deer are another natural reservoir and the source of the atypical GUD ${ }^{+}$STEC isolates in Hokkaido.

Feng et al. [39] have proposed an evolutionary model for the emergence of the E. coli $\mathrm{O} 157: \mathrm{H} 7$ complex of strains based on mutation in uidA, Stx production, SOR and GUD phenotypes, and their multilocus enzyme electrophoretic profile. In it, the EPEC-like strain of O55:H7 is a common ancestor of the O157:H7 complex, although it has the uidA -10 mutation (A to $\mathrm{T}$ ) and $\mathrm{SOR}^{+}$and $\mathrm{GUD}^{+}$phenotypes. The model predicts that the atypical $\mathrm{SOR}^{+}$and $\mathrm{GUD}^{+} \mathrm{STEC}$ $\mathrm{O} 157: \mathrm{H}^{-}$isolates in Europe and the GUD ${ }^{+}$STEC O157:H7 isolate in USA were derived from the EPEClike O55:H7 strain because these two atypical strains had an identical mutation at uidA +92 allele ( $\mathrm{T}$ to $\mathrm{G}$ ) [39]. PCR performed on the atypical STEC O157:H7 Hokkaido isolates for a possible mutation in the same uidA +92 allele with a primer set covering this site [30] indicated the presence of the same mutation at the uidA +92 site (data not shown). This feature, together with the traits of $\mathrm{SOR}^{-}$and $\mathrm{GUD}^{+}$phenotypes and Stx1 and Stx2 production, suggests that the GUD ${ }^{+}$ STEC O157:H7 isolates obtained in Hokkaido were derived from E. coli $\mathrm{O} 55: \mathrm{H} 7$. Therefore, they locate more closely to the atypical GUD ${ }^{+}$O157:H7 US strain than to the $\mathrm{GUD}^{+} \mathrm{O} 157: \mathrm{H}^{-}$European strains in their evolution.

\section{References}

1. Tarr PI. Escherichia coli O157:H7: clinical, diagnostic, and epidemiological aspects of human infection. Clin Infect Dis 1995; 20: $1-10$.

2. O'Brien AD, Holmes RK. Shiga and Shiga-like toxins. Microbiol Rev 1987; 51: 206-220.

3. Melton-Celsa AR, O'Brien A. Structure, biology, and relative toxicity of Shiga toxin family members for cells and animals In: Kaper JB, O'Brien AD (eds) Escherichia coli O157:H7 and other Shiga toxin-producing E. coli strains. Washington, DC, American Society for Microbiology. 1998: 121-128.

4. Louise CB, Obrig TG. Shiga toxin-associated hemolytic uremic syndrome combined cytotoxic effects of shiga toxin and lipopolysaccharide (endotoxin) on human vascular endothelial cells in vitro. Infect Immun 1992; 60: 1536-1543.

5. Kaper JB, Elliotto S, Sperandio V, Perna NT, Mayhew GF, Blattner FR. Attaching-and-effacing intestinal histopathology and the locus of enterocyte effacement. In: Kaper JB, O'Brien AD (eds) Escherichia coli O157:H7 and other Shiga toxinproducing E. coli strains. Washington, DC, American Society for Microbiology. 1998: 163-182.

6. Jarvis $\mathrm{KG}$, Kaper JB. Secretion of extracellular proteins by enterohemorrhagic Escherichia coli via a putative type III secretion system. Infect Immun 1996; 64: 4826-4829.

7. Kresse AU, Schulze K, Deibel C et al. Pas, a novel protein required for protein secretion and attaching and effacing activities of enterohemorrhagic Escherichia coli. J Bacteriol 1998; 180: 4370-4379.

8. Schmidt H, Beutin L, Karch H. Molecular analysis of the plasmid-encoded hemolysin of Escherichia coli O157:H7 strain EDL 933. Infect Immun 1995; 63: 1055-1061.

9. Schmidt H, Maier E, Karch H, Benz R. Pore-forming properties of the plasmid-encoded hemolysin of enterohemorrhagic Escherichia coli O157:H7. Eur J Biochem 1996; 241 594-601.

10. Brunder W, Schmidt H, Karch H. KatP, a novel catalaseperoxidase encoded by the large plasmid of enterohaemorrhagic Escherichia coli O157:H7. Microbiology 1996; 142: 3305-3315.

11. Brunder W, Schmidt H, Karch H. EspP, a novel extracellular serine protease of enterohaemorrhagic Escherichia coli O157:H7 cleaves human coagulation factor V. Mol Microbiol 1997; 24: 767-778.

12. Brunder W, Schmidt H, Frosch M, Karch $H$. The large plasmids of Shiga-toxin-producing Escherichia coli (STEC) are 
highly variable genetic elements. Microbiology 1999; 145 1005-1014.

13. Schmidt H, Henkel B, Karch H. A gene cluster closely related to type II secretion pathway operons of gram-negative bacteria is located on the large plasmid of enterohemorrhagic Escherichia coli $\mathrm{O} 157: \mathrm{H} 7$ strains. FEMS Microbiol Lett 1997; 148: 265-272.

14. Izumiya $\mathrm{H}$, Terajima $\mathrm{J}$, Wada A et al. Molecular typing of enterohemorrhagic Escherichia coli O157:H7 isolates in Japan by using pulsed-field gel electrophoresis. J Clin Microbiol 1997; 35: 1675-1680.

15. National Institute of Health and Infectious Disease Control Division, Ministry of Health and Welfare of Japan. Enterohemorrhagic Escherichia coli (verotoxin-producing E. coli) infection, 1996-April 1998. Infectious Surveillance Rep 1998; 19: $122-123$.

16. Watanabe $\mathrm{H}$, Wada A, Inagaki Y, Itoh $\mathrm{K}$, Tamura K. Outbreaks of enterohaemorrhagic Escherichia coli O157:H7 infection by two different genotype strains in Japan, 1996. Lancet 1996; 348: $831-832$.

17. Doyle MP, Schoeni JL. Survival and growth characteristics of Escherichia coli associated with hemorrhagic colitis. Appl Environ Microbiol 1984; 48: 855-856.

18. March SB, Ratnam S. Sorbitol-MacConkey medium for detection of Escherichia coli O157:H7 associated with hemorrhagic colitis. J Clin Microbiol 1986; 23: 869-872.

19. Feng P. Escherichia coli serotype O157:H7: novel vehicles of infection and emergence of phenotypic variants. Emerg Infect Dis 1995; 1: 47-52.

20. Okrend AJG, Rose BE, Lattuada CP. Use of 5-bromo-4-chloro3 -indoxyl- $\beta$-D-glucuronidase in MacConkey sorbitol agar to aid in the isolation of Escherichia coli $\mathrm{O} 157: \mathrm{H} 7$ in ground beef. J Food Prot 1990; 53: 941-943.

21. Thompson JS, Hodge DS, Borczyk AA. Rapid biochemical test to identify verotoxin-positive strains of Escherichia coli serotype O157. J Clin Microbiol 1990; 28: 2165-2168.

22. Gunzer F, Böhm H, Rüssmann H, Bitzan M, Aleksic S, Karch H. Molecular detection of sorbitol-fermenting Escherichia coli O157 in patients with hemolytic-uremic syndrome. J Clin Microbiol 1992; 30: 1807-1810.

23. Bielaszewska M, Schmidt H, Karmali MA et al. Isolation and characterization of sorbitol-fermenting shiga toxin (verocytotoxin)-producing Escherichia coli $\mathrm{O} 157: \mathrm{H}-$ strains in the Czech Republic. J Clin Microbiol 1998; 36: 2135-2137.

24. Hayes PS, Blom K, Feng P, Lewis J, Strockbine NA, Swaminathan BS. Isolation and characterization of a $\beta$-Dglucuronidase-producing strain of Escherichia coli serotype O157:H7 in the United States. J Clin Microbiol 1995; 33: $3347-3348$.

25. Karch H, Böhm H, Schmidt H, Gunzer F, Aleksic S, Heesemann J. Clonal structure and pathogenicity of shiga-like toxin-producing, sorbitol-fermenting Escherichia coli O157: H-. J Clin Microbiol 1993; 31: 1200-1205.
26. Murray PR, Baron EJ, Pfaller MA, Tenover FC, Yolken RH (eds) Manual of clinical microbiology, 6th edn. Washington, DC, ASM Press. 1995.

27. Beutin L, Monteneglo MA, Orskov I et al. Close association of verotoxin (Shiga-like toxin) production with enterohemolysin production in strains of Escherichia coli. J Clin Microbiol 1989; 27: 2559-2564.

28. Schmidt H, Geitz C, Tarr PI, Frosch M, Karch H. NonO157:H7 pathogenic shiga toxin-producing Escherichia coli: phenotypic and genetic profiling of virulence traits and evidence for clonality. $J$ Infect Dis 1999; 179: 115-123.

29. Sambrook J, Fritsch EF, Maniatis T. Molecular cloning: a laboratory manual, 2nd edn. Cold Spring Harbor, NY, Cold Spring Harbor Laboratory Press. 1989.

30. Cebula TA, Payne WL, Feng P. Simultaneous identification of strains of Escherichia coli serotype O157:H7 and their shigalike toxin type by mismatch amplification mutation assaymultiplex PCR. J Clin Microbiol 1995; 33: 248-250.

31. Oswald E, Schmidt H, Morabito S, Karch H, Marchès O, Caprioli A. Typing of intimin genes in human and animal enterohemorrhagic and enteropathogenic Escherichia coli: characterization of a new intimin variant. Infect Immun 2000; 68: $64-71$.

32. Tenover FC, Arbeit RD, Goering RV et al. Interpreting chromosomal DNA restriction patterns produced by pulsedfield gel electrophoresis: criteria for bacterial strain typing. J Clin Microbiol 1995; 33: 2233-2239.

33. McDaniel TK, Jarvis KG, Donnenberg NS, Kaper JB. A genetic locus of enterocyte effacement conserved among diverse enterobacterial pathogens. Proc Natl Acad Sci USA 1995; 92: 1664-1668.

34. Schmidt H, Kernbach C, Karch H. Analysis of the EHEC hly operon and its location in the physical map of the large plasmid of enterohaemorrhagic Escherichia coli O157:H7. Microbiology 1996; 142: 907-914.

35. Schmidt H, Karch H, Beutin L. The large-sized plasmid of enterohemorrhagic Escherichia coli 0157 strains encode hemolysins which are presumably members of the E. coli $\alpha$ hemolysin family. FEMS Microbiol Lett 1994; 117: 189-196.

36. Bielaszewska M, Schmidt H, Liesegang A et al. Cattle can be a reservoir of sorbitol-fermenting shiga toxin-producing Escherichia coli O157:H- strains and a source of human diseases. J Clin Microbiol 2000; 38: 3470-3473.

37. Terajima $J$, Izumiya $H$, Wada $A$, Tamura $K$, Watanabe $H$. Shiga toxin-producing Escherichia coli O157:H7 in Japan. Emerg Infect Dis 1999; 5: 301-302.

38. Ammon A, Petersen LR, Karch H. A large outbreak of hemolytic uremic syndrome caused by an unusual sorbitolfermenting strain of Escherichia coli $\mathrm{O} 157: \mathrm{H}^{-}$. J Infect Dis 1999; 179: 1274-1277.

39. Feng P, Lampel KA, Karch H, Whittam TS. Genotypic and phenotypic changes in the emergence of Escherichia coli O157:H7. J Infect Dis 1998; 177: 1750-1753. 